\title{
Molecular and biochemical characterization of urease and survival of Yersinia enterocolitica biovar IA in acidic $\mathrm{pH}$ in vitro Neeru Bhagat and Jugsharan S Virdi*
}

Address: Microbial Pathogenicity Laboratory, Department of Microbiology, University of Delhi South Campus, Benito Juarez Road, New Delhi 110021 , India

Email: Neeru Bhagat - neeru_bhagat@yahoo.com; Jugsharan S Virdi* - virdi_dusc@rediffmail.com

* Corresponding author

Published: 17 December 2009

BMC Microbiology 2009, 9:262 doi:10.1186/147|-2/80-9-262

This article is available from: http://www.biomedcentral.com/I47I-2/80/9/262

(C) 2009 Bhagat and Virdi; licensee BioMed Central Ltd

This is an Open Access article distributed under the terms of the Creative Commons Attribution License (http://creativecommons.org/licenses/by/2.0), which permits unrestricted use, distribution, and reproduction in any medium, provided the original work is properly cited.
Received: 20 May 2009

Accepted: 17 December 2009

\begin{abstract}
Background: Yersinia enterocolitica, an important food- and water-borne enteric pathogen is represented by six biovars viz. IA, IB, 2, 3, 4 and 5. Despite the lack of recognized virulence determinants, some biovar IA strains have been reported to produce disease symptoms resembling that produced by known pathogenic biovars (IB, 2-5). It is therefore imperative to identify determinants that might contribute to the pathogenicity of $Y$. enterocolitica biovar IA strains. $Y$. enterocolitica invariably produces urease and the role of this enzyme in the virulence of biovar IB and biovar 4 strains has been reported recently. The objective of this work was to study genetic organization of the urease (ure) gene complex of $Y$. enterocolitica biovar IA, biochemical characterization of the urease, and the survival of these strains under acidic conditions in vitro.

Results: The ure gene complex (ureABCEFGD) of $Y$. enterocolitica biovar IA included three structural and four accessory genes, which were contiguous and was flanked by a urea transport (yut) gene on the $3^{\prime}$ side. Differences were identified in ure gene complex of biovar IA strain compared to biovar IB and 4 strains. This included a smaller ure $B$ gene and larger intergenic regions between the structural genes. The crude urease preparation exhibited optimal $\mathrm{pH}$ and temperature of 5.5 and $65^{\circ} \mathrm{C}$ respectively, and Michaelis-Menten kinetics with a $\mathrm{K}_{\mathrm{m}}$ of $\mathrm{I} .7 \pm 0.4 \mathrm{mM}$ urea and $V_{\max }$ of $7.29 \pm 0.42 \mu \mathrm{mol}$ of ammonia released $/ \mathrm{min} / \mathrm{mg}$ protein. The urease activity was dependent on growth temperature and growth phase of $Y$. enterocolitica biovar IA, and the presence of nickel in the medium. The molecular mass of the enzyme was $>545 \mathrm{kDa}$ and an isoelectric point of 5.2. The number of viable $Y$. enterocolitica biovar IA decreased significantly when incubated at $\mathrm{pH} 2.5$ for $2 \mathrm{~h}$. However, no such decrease was observed at this $\mathrm{pH}$ in the presence of urea.
\end{abstract}

Conclusions: The ure gene cluster of biovar IA strains though similar to biovar IB and 4 strains, exhibited important differences. The study also showed the ability of biovar IA strains of $Y$. enterocolitica to survive at highly acidic $\mathrm{pH}$ in vitro in the presence of urea.

\section{Background}

Yersinia enterocolitica, an important food- and water-borne human enteropathogen is known to cause a variety of gastrointestinal problems. Most commonly, it causes acute diarrhea, terminal ileitis and mesenteric lymphadenitis [1]. Long-term sequelae following infection include reactive arthritis and erythema nodosum [1]. Blood transfusion associated septicemia due to Y. enterocolitica has been 
reported to have high mortality [2]. Currently, Y. enterocolitica is represented by six biovars (1A, 1B, 2, 3, 4 and 5) and more than 30 distinct serovars. The virulence of known pathogenic biovars namely $1 \mathrm{~B}$ and $2-5$ is attributed to pYV (plasmid for Yersinia virulence) plasmid [3] and chromosomally borne virulence factors [4].

The biovar 1A strains however lack pYV plasmid and have generally been regarded as avirulent. But several clinical, epidemiological and experimental evidences indicate their potential pathogenicity [5]. Some biovar 1A strains have been reported to produce disease symptoms resembling that produced by pathogenic biovars [6,7]. These have been implicated in nosocomial [8] and food-borne [9] outbreaks and isolated from extra-intestinal sites [10]. The biovar 1A strains also invade epithelial cells [11,12], resist killing by macrophages [13] and carry virulenceassociated genes such as $y s t B$ (enterotoxin), inv (invasin), $m y f A$ (fimbriae), hreP (subtilisin/kexin-like protease) and tccC (insecticidal-toxin like complex) $[5,14]$. In the past, enterotoxin has been thought to be the only major virulence factor produced by biovar 1A strains. Recently insecticidal-toxin complex [15] and flagella [16] have been identified as virulence factors of $Y$. enterocolitica biovar 1A strains. However the exact mechanisms underlying the pathogenesis by biovar 1A strains remains unclear and there is need to investigate the role of other putative virulence factors.

Urease (urea amidohydrolase; EC 3.5.1.5) has been implicated to play a role in the pathogenesis of many bacteria such as Helicobacter pylori, Proteus mirabilis and Brucella abortus [17-19]. Y. enterocolitica invariably produces urease which has been reported to enable biovar 1B and biovar 4 strains to survive in the acidic environment of the stomach $[20,21]$. However, the role of urease in the survival of biovar 1A strains has not been investigated. The objective of this study was to determine the genetic organization of urease (ure) gene cluster, factors affecting urease activity, and the survival of biovar 1A strain of Y. enterocolitica in acidic $\mathrm{pH}$ in vitro.

\section{Methods}

\section{Bacterial strains and growth conditions}

$Y$. enterocolitica biovar 1A (serovar O:6,30) isolated from the stools of a diarrheic patient and deposited with Yersinia National Reference Laboratory and WHO Collaborating Center, Pasteur Institute (Paris) under reference number IP27403 was used to characterize ure gene complex and the enzyme urease. The details of other Y. enterocolitica strains used in this study namely serovars, source of isolation, country of origin, reference laboratory accession numbers and clonal groups have been reported previously [22]. Y. enterocolitica 8081 (bioserovar 1B/O:8) was obtained from M. Skurnik (Haartman Institute, Hel- sinki, Finland). Y. enterocolitica IP26329 (bioserovar 2/ O:9), IP26249 (bioserovar 2/O:5,27), and IP134 (bioserovar 4/O:3) were obtained from E. Carniel (Yersinia National Reference Laboratory and WHO Collaborating Center, Pasteur Institute, France). All strains were grown overnight at $28^{\circ} \mathrm{C}$ in Luria broth (HiMedia, Mumbai, India).

\section{DNA extraction, primers and Polymerase Chain Reaction} Genomic DNA was isolated from overnight grown cultures using DNeasy tissue kit (Qiagen $\mathrm{GmbH}$ ) as reported earlier [14].

Urease gene sequences of $Y$. enterocolitica biovar $1 \mathrm{~B}$ and biovar 4 with GenBank accession numbers L24101[23] and $\underline{Z 18865}[24]$ respectively were used to design primers U1 and U2 using PrimerSelect 5.03 software (DNASTAR Inc., Madison, USA) such that the structural genes (ureA, ure $B$, ure $C$ ) may be amplified as one amplicon. As these primers failed to consistently amplify the ure $A B C$ region of biovar 1A strains, primers for amplification of each of the structural genes separately were designed from the following sequences in the database (accession numbers are given in parentheses): Y. enterocolitica biovar 1B (L24101, AM286415), Y. enterocolitica biovar 4 (Z18865), Y. aldovae (AY363680), Y. bercovieri (AY363681), Y. frederiksenii (AY363682), Y. intermedia (AY363683), Y. kristensenii (AY363684), Y. mollaretii (AY363685), Y. rohdei (AY363686), Y. pestis (AE017042, AL590842, AE009952, AF095636) and $Y$. pseudotuberculosis (U40842, BX936398). These sequences were also used to design primers for ure accessory (ureE, ureF, ureG, ureD) and urea transport $(y u t)$ genes. The most conserved regions for each of the genes were identified using MegAlign (DNASTAR) or ClustalW version 1.83 (accessible at http:// www.ebi.ac.uk/tools/clustalW).

Primer pairs - ureA1-ureA2 (for ureA), ureB1-ureB2 (for ureB), ureC1-ureC2 (for ureC), ureCE1-ureCE2 (for ureCureE and ureE), ureF1-ureF2 (for ureF), ureG1-ureG2 (for ureG), ureD1-ureD2 (for ureD) and yut1-yut2 (for yut) were designed from the conserved regions (Fig. 1) with PrimerSelect software. The sequences of the amplicons thus obtained (with strain IP27403) were used subsequently to design primers for the intergenic regions and a remaining part of the ure $C$ gene. The intergenic regions between ureA-ureB, ureB-ureC, ureE-ureF, ureF-ureG and ureD-yut were amplified using primer pairs - ureAB1ureAB2, ureBC1-ureBC2, ureE1-ureE2, ureFG1-ureFG2 and ureD3-ureD4 respectively and part of ureC gene by ureC3-ureC4. As ureD could not be amplified in biovar $1 \mathrm{~A}$ strain with ureD1-ureD2, another primer pair ureG1ureD2 was used for amplification of the ureG-ureD intergenic region and ureD gene. The primers were synthesized 
from Microsynth or Sigma Genosys. The details of the PCR primers and the target genes are given in Table 1.

PCRs for ure structural and accessory genes, intergenic regions and the yut gene were performed using a thermal cycler (MyCycler, Bio-Rad). The $25 \mu \mathrm{l}$ PCR reaction mixture contained $100 \mathrm{ng}$ of genomic DNA, $2.5 \mu \mathrm{l}$ of $10 \times \mathrm{Taq}$ buffer containing $1.5 \mathrm{mM} \mathrm{MgCl}_{2}, 2.5 \mu \mathrm{l}$ of $2 \mathrm{mM} \mathrm{dNTP,}$ 25 pmol of each primer, and $2 \mathrm{U}$ of Taq DNA polymerase (New England BioLabs). The details of the conditions used for amplification are given in Table 1. After amplification, $10 \mu \mathrm{l}$ of the PCR product was resolved in $2 \%$ agarose gel in $1 \times$ Tris-acetate-ethylenediaminetetraacetic acid (TAE) buffer ( $40 \mathrm{mM}$ Tris-HCl, $20 \mathrm{mM}$ acetic acid, $1 \mathrm{mM}$ EDTA, pH 8.0) at $70 \mathrm{~V}$ for $2 \mathrm{~h}$. The gels were stained with ethidium bromide $(0.5 \mu \mathrm{g} / \mathrm{ml})$ and photographed under UV-transillumination in a gel documentation system (Bio-Rad, CA). The $1 \mathrm{~kb}$ and $100 \mathrm{bp}$ DNA ladders (New England BioLabs) served as molecular size markers.

\section{Sequencing of PCR amplicons, ORF analysis and phylogenetic relationships}

The PCR amplicons obtained above using the genomic DNA of Y. enterocolitica biovar 1A (strain IP27403) were extracted, purified using QIAquick Gel extraction kit (Qiagen) and sequenced directly in one or both directions (Microsynth, Balgach, Switzerland or LabIndia, Gurgaon, India). The sequences were analyzed, edited and compiled using Editseq and MegAlign of DNASTAR. Homology searches for nucleotide and deduced amino acid sequences were carried out by BLASTN and BLASTP respectively. The multiple nucleotide and protein sequence alignments were performed by MegAlign or ClustalW. The percent identity and similarity were calculated using MatGAT 2.02 [25]. The theoretical molecular weight and isoelectric point (pI) of urease structural and accessory proteins were determined by EditSeq (DNASTAR).

The open reading frames (ORFs) in the compiled ure gene cluster were identified using GeneMark [26], GeneMark.hmm [27], FGENESB [28] and the NCBI ORF finder [29] programs. All ORFs were checked further for homology to known protein sequences using BLASTX.

The relationship of urease structural and accessory protein sequences of biovar $1 \mathrm{~A}$ strain of $Y$. enterocolitica to sequences available in GenBank were determined by constructing phylogenetic trees with the program MEGA 4.0 using the neighbor-joining algorithm. Bootstrap value for each node of the tree was calculated over 1,000 replicate trees.

\section{PCR-Restriction fragment length polymorphism (PCR- RFLP) of urease genes}

Primer pairs ureAB3-ureAB4 and ureC1-ureC4 were designed to amplify the 1,004 bp and 1,727 bp of ureAB and ure $C$ genes respectively (Fig. 1). The biovar $1 \mathrm{~A}$ strains were chosen such that each belonged to a different serovar, country, source of isolation, REP/ERIC-type [22] and VNTR01-type [30]. The PCR amplicon of ureAB was digested with HaeIII and Sau96I while that of ureC was digested with RsaI and Sau96I. The choice of the restriction enzymes was based on in silico restriction of the expected amplicons such that DNA fragments were amenable to separation by gel electrophoresis. Restriction enzymes were from New England BioLabs (RsaI and HaeIII) or Bangalore Genei (Sau96I). Ten microlitre of amplified DNA was digested with $2.5 \mathrm{U}$ (HaeIII and Sau96I) or 5 U (RsaI) of restriction enzyme using appropriate buffer recommended by the manufacturer, in a total volume of $25 \mu \mathrm{l}$ at $37^{\circ} \mathrm{C}$ overnight. The digested products were separated by electrophoresis in $2.5 \%$ agarose gel at $50 \mathrm{~V}$ for $5 \mathrm{~h}$ in TAE buffer. 100 bp ladder (New England BioLabs) was used as the molecular size standard. The gel was stained with ethidium bromide and examined under UV transillumination.

\section{Growth and preparation of cell free extract}

$Y$. enterocolitica strain IP27403 was grown overnight at $28^{\circ} \mathrm{C}$ in $20 \mathrm{ml} \mathrm{LB}$ medium with shaking at $200 \mathrm{rpm}$. Cells were collected by centrifugation $\left(9,000 \times g, 10 \mathrm{~min}, 4^{\circ} \mathrm{C}\right)$, washed twice, and resuspended to $1.5 \times 10^{8} \mathrm{CFU} / \mathrm{ml}$ equivalent to $0.5 \mathrm{McF}$ arland standard $\left(\mathrm{A}_{600}=0.1\right)$. These were diluted to $1.0 \times 10^{6} \mathrm{CFU} / \mathrm{ml}$ and $50 \mu \mathrm{l}$ of this suspension was inoculated into $50 \mathrm{ml}$ of fresh LB medium, and incubated further $\left(28^{\circ} \mathrm{C}\right.$, shaking at $\left.200 \mathrm{rpm}\right)$. Samples were withdrawn at different time intervals up to $78 \mathrm{~h}$ and diluted in $20 \mathrm{mM}$ sodium phosphate buffer ( $\mathrm{pH} 7.0) .0 .1$ $\mathrm{ml}$ of the appropriate dilution was plated, in triplicate, on Luria agar and incubated overnight at $28^{\circ} \mathrm{C}$. The number of viable bacteria was recorded at different intervals and $\mathrm{CFU} / \mathrm{ml}$ was calculated. The $\log _{10} \mathrm{CFU} / \mathrm{ml}$ was plotted against incubation time (in $\mathrm{h}$ ).

For preparing lysate, cells grown in $50 \mathrm{ml} \mathrm{LB}$ medium were harvested by centrifugation, washed twice and resuspended in $2.5 \mathrm{ml}$ of $20 \mathrm{mM}$ sodium phosphate buffer $(\mathrm{pH}$ $7.0)$. Cells were disrupted by sonication with three cycles (2 s "pulse on" and $2 \mathrm{~s}$ "pulse off" for $2 \mathrm{~min}$ ) at $25 \%$ intensity with Vibra-Cell (Sonics). The cell lysate was centrifuged at $18,000 \times \mathrm{g}$ for $30 \mathrm{~min}$ at $4^{\circ} \mathrm{C}$ to obtain cell-free extract. The supernatant was transferred to pre-chilled microcentrifuge tubes and used immediately for determination of urease activity. Protein concentration was estimated by Bradford [31] method using bovine serum albumin (Sigma) as standard. 
Table I: PCR amplification of urease structural (ure $A$, ure $B$, ure $C$ ) and the accessory (ure $E$, ureF, ure $G$, ure $D$ ) genes and the intergenic regions thereof, in $Y$. enterocolitica biovar IA strain.

\begin{tabular}{|c|c|c|c|c|c|c|c|c|}
\hline \multirow[t]{2}{*}{ Primer } & \multirow[t]{2}{*}{ Sequence (5' - 3') } & \multirow[t]{2}{*}{ Target } & \multirow[t]{2}{*}{ Accession no. } & \multirow[t]{2}{*}{ Region amplified } & \multirow{2}{*}{$\begin{array}{l}\text { Amplicon length } \\
\text { (bp) }\end{array}$} & \multicolumn{3}{|c|}{ PCR conditions $\left({ }^{\circ} \mathrm{C}, \mathrm{s}\right)^{*}$} \\
\hline & & & & & & Den & Ann & Ext \\
\hline $\begin{array}{l}\text { UI } \\
\text { U2 }\end{array}$ & $\begin{array}{l}\text { GCAGCCGTTTGGTC } \\
\text { ACGG } \\
\text { CTATGCCACGCATC } \\
\text { CCGACC }\end{array}$ & ureA-ureC & $\begin{array}{l}\frac{D Q 350880}{A M 286415} \\
\underline{\text { ZI8865 }}\end{array}$ & $\begin{array}{l}275 \ldots 2896 \\
1075847 \ldots 1078426 \\
325 \ldots 2907\end{array}$ & $\begin{array}{l}2622 \\
2580 \\
2582\end{array}$ & 94,60 & $62.0,110$ & 72,110 \\
\hline $\begin{array}{l}\text { ureAl } \\
\text { ureA2 }\end{array}$ & $\begin{array}{l}\text { GGAGGGCTTATGCA } \\
\text { GCTCACCCCAAG } \\
\text { TTGCCATCTCTGGC } \\
\text { CCCTTCCA }\end{array}$ & ureA & $\begin{array}{l}\frac{D Q 350880}{A M 286415} \\
\frac{\text { ZI8865 }}{}\end{array}$ & $\begin{array}{l}|\ldots| 6 \mid \\
1075573 \ldots 1075733 \\
5|. .21|\end{array}$ & $\begin{array}{l}161 \\
161 \\
161\end{array}$ & 94,60 & $61.4,60$ & 72,60 \\
\hline $\begin{array}{l}\text { ureABI } \\
\text { ureAB2 }\end{array}$ & $\begin{array}{l}\text { CAATGGAAGGGGCC } \\
\text { AGAGATGG } \\
\text { GTAAGCCGCAGCAC } \\
\text { GGTCAAACTC }\end{array}$ & ureA-ureB & $\begin{array}{l}\frac{D Q 350880}{A M 286415} \\
\underline{\text { ZI8865 }}\end{array}$ & $\begin{array}{l}\mid 37 \ldots 579 \\
1075709 \ldots 1076210 \\
\mid 87 \ldots 688\end{array}$ & $\begin{array}{l}443 \\
502 \\
502\end{array}$ & 94,60 & $60.3,60$ & 72,60 \\
\hline $\begin{array}{l}\text { ureAB3 } \\
\text { ureAB4 }\end{array}$ & $\begin{array}{l}\text { GCAGCTCACCCCAA } \\
\text { GAGAAGTTGA } \\
\text { AATTTGAGGCATCT } \\
\text { GTCGCTCCTT }\end{array}$ & ureA-ureB & $\frac{\frac{\mathrm{DQ} 350880}{\mathrm{AM} 286415}}{\underline{\mathrm{ZI} 8865}}$ & $\begin{array}{l}12 \ldots 1015 \\
1075584 \ldots 1076608 \\
62 \ldots 1086\end{array}$ & $\begin{array}{l}1004 \\
1025 \\
1025\end{array}$ & 95,60 & $56.9,110$ & 72,60 \\
\hline $\begin{array}{l}\text { ureBI } \\
\text { ureB2 }\end{array}$ & $\begin{array}{l}\text { ATTGCAGAGGATTA } \\
\text { AAGCATGAGC } \\
\text { AGCGGAACTTCGGT } \\
\text { TTCATCACC }\end{array}$ & ureB & $\begin{array}{l}\frac{D Q 350880}{A M 286415} \\
\underline{\text { ZI8865 }}\end{array}$ & $\begin{array}{l}349 \ldots 650 \\
1075920 \ldots 1076281 \\
398 \ldots 759\end{array}$ & $\begin{array}{l}302 \\
362 \\
362\end{array}$ & 94,60 & $60.0,60$ & 72,60 \\
\hline $\begin{array}{l}\text { ureBCl } \\
\text { ureBC2 }\end{array}$ & $\begin{array}{l}\text { TGCGGCTTACGGAA } \\
\text { AAAGGCTGAATA } \\
\text { GCCGAGAAATTTGA } \\
\text { GGCATCTGTCG }\end{array}$ & ureB-ureC & $\begin{array}{l}\frac{\mathrm{DQ} 350880}{\mathrm{AM} 286415} \\
\underline{\mathrm{ZI} 8865}\end{array}$ & $\begin{array}{l}570 \ldots 1022 \\
1076201 \ldots 1076615 \\
679 \ldots 1093\end{array}$ & $\begin{array}{l}453 \\
415 \\
415\end{array}$ & 94,60 & $60.3,60$ & 72,60 \\
\hline $\begin{array}{l}\text { ureCl } \\
\text { ureC2 }\end{array}$ & $\begin{array}{l}\text { AAAGGAGCGACAGA } \\
\text { TGCCTCAAA } \\
\text { GAAACCTGAATATC } \\
\text { CATTTCATCCGCCA } \\
\mathrm{T}\end{array}$ & ureC & $\frac{\frac{D Q 350880}{A M 286415}}{\underline{\text { ZI8865 }}}$ & $\begin{array}{l}991 \ldots 1749 \\
1076584 \ldots 1077342 \\
1062 \ldots 1823\end{array}$ & $\begin{array}{l}759 \\
759 \\
762\end{array}$ & 94,60 & $63.2,60$ & 72,60 \\
\hline $\begin{array}{l}\text { ureC3 } \\
\text { ureC4 }\end{array}$ & $\begin{array}{l}\text { GGCTATAAAGTTCA } \\
\text { CGAAGACTG } \\
\text { CAAAGAAATAGCGC } \\
\text { TGGTTCA }\end{array}$ & ureC & $\begin{array}{l}\frac{\mathrm{DQ} 350880}{\mathrm{AM} 286415} \\
\underline{\text { Z18865 }}\end{array}$ & $\begin{array}{l}|661 \ldots 27| 7 \\
1077254 \ldots 1078310 \\
|735 \ldots 279|\end{array}$ & $\begin{array}{l}1057 \\
1057 \\
1057\end{array}$ & 94,60 & $52.9,60$ & 72,60 \\
\hline $\begin{array}{l}\text { ureCl } \\
\text { ureC4 }\end{array}$ & $\begin{array}{l}\text { AAAGGAGCGACAGA } \\
\text { TGCCTCAAA } \\
\text { CAAAGAAATAGCGC } \\
\text { TGGTTCA }\end{array}$ & ureC & $\frac{\frac{D Q 350880}{A M 286415}}{\underline{\text { ZI8865 }}}$ & $\begin{array}{l}991 \ldots 27 \mid 7 \\
1076584 \ldots 1078310 \\
|062 \ldots 279|\end{array}$ & $\begin{array}{l}1727 \\
1727 \\
1730\end{array}$ & 94,60 & $50.0,60$ & 72,120 \\
\hline $\begin{array}{l}\text { ureCEI } \\
\text { ureCE2 }\end{array}$ & $\begin{array}{l}\text { GCGCTGGATGACGG } \\
\text { TGTGAAAGAG } \\
\text { ATGTAAGCCGGAGC } \\
\text { CATGAGGTTC }\end{array}$ & ureC-ureE, ureE & $\begin{array}{l}\mathrm{DQ} 350880 \\
\mathrm{AM} 286415\end{array}$ & $\begin{array}{l}2504 \ldots 3552 \\
1078097 \ldots 1079082\end{array}$ & $\begin{array}{c}1019 \\
986\end{array}$ & 94,60 & $61.0,60$ & 72,60 \\
\hline $\begin{array}{l}\text { ureEI } \\
\text { ureE2 }\end{array}$ & $\begin{array}{l}\text { ACCATGATGGATTC } \\
\text { CGTGATGAGA } \\
\text { GTGAAGGCCCCGAC } \\
\text { CGGCAGTACG }\end{array}$ & ureE-ureF & $\begin{array}{l}\text { DQ350880 } \\
\text { AM286415 }\end{array}$ & $\begin{array}{l}3364 \ldots 3734 \\
1078894 \ldots 1079270\end{array}$ & $\begin{array}{l}371 \\
377\end{array}$ & 95,60 & $58.7,60$ & 72,60 \\
\hline $\begin{array}{l}\text { ureFI } \\
\text { ureF2 }\end{array}$ & $\begin{array}{l}\text { TGAATGCATCAGAT } \\
\text { CTGATTCGTA } \\
\text { ACATCCACAATAGG } \\
\text { GACATAAGA }\end{array}$ & ureF & $\begin{array}{l}\text { DQ350880 } \\
\underline{A M 286415}\end{array}$ & $\begin{array}{l}3668 \ldots 4304 \\
1079204 \ldots 1079840\end{array}$ & $\begin{array}{l}637 \\
637\end{array}$ & 95,60 & $50.0,60$ & 72,60 \\
\hline
\end{tabular}


Table I: PCR amplification of urease structural (ureA, ureB, ureC) and the accessory (ureE, ureF, ureG, ure $D$ ) genes and the intergenic regions thereof, in Y. enterocolitica biovar IA strain. (Continued)

\begin{tabular}{|c|c|c|c|c|c|c|c|c|}
\hline $\begin{array}{l}\text { ureFGI } \\
\text { ureFG2 }\end{array}$ & $\begin{array}{l}\text { CAATATGGCGTGGC } \\
\text { GATGACAAT } \\
\text { CCACCGGGCCACC } \\
\text { AATACCAA }\end{array}$ & ureF-ureG & $\begin{array}{l}\text { DQ350880 } \\
\text { AM2864I5 }\end{array}$ & $\begin{array}{l}4132 \ldots 4535 \\
1079668 \ldots 1080070\end{array}$ & $\begin{array}{l}403 \\
401\end{array}$ & 95,60 & $55.7,60$ & 72,60 \\
\hline $\begin{array}{l}\text { ureGI } \\
\text { ureG2 }\end{array}$ & $\begin{array}{l}\text { GAATAGCCATTCAA } \\
\text { CCGATAAAC } \\
\text { CGCATAATCATATC } \\
\text { CACCAAC }\end{array}$ & ureG & $\frac{\mathrm{DQ} 350880}{\underline{\mathrm{AM} 286415}}$ & $\begin{array}{l}4474 \ldots 509 \mid \\
1080009 \ldots 1080626\end{array}$ & $\begin{array}{l}618 \\
618\end{array}$ & 95,60 & $51.3,60$ & 72,60 \\
\hline $\begin{array}{l}\text { ureGI } \\
\text { ureD2 }\end{array}$ & $\begin{array}{l}\text { GAATAGCCATTCAA } \\
\text { CCGATAAAC } \\
\text { TTCCGGCAATGTCA } \\
\text { CACCGAGAAT }\end{array}$ & ureG-ure $D$, ure $D$ & $\begin{array}{l}\text { DQ350880 } \\
\text { AM2864I5 }\end{array}$ & $\begin{array}{l}4474 \ldots 6099 \\
1080009 \ldots 1081634\end{array}$ & $\begin{array}{l}1626 \\
1626\end{array}$ & 95,60 & $50.4,60$ & 72,120 \\
\hline $\begin{array}{l}\text { ureDI } \\
\text { ureD2 }\end{array}$ & $\begin{array}{l}\text { AGCCAGAATATCGT } \\
\text { GGAAACTCCT } \\
\text { TTCCGGCAATGTCA } \\
\text { CACCGAGAAT }\end{array}$ & ure $D$ & $\frac{\text { DQ350880 }}{\text { AM286415 }}$ & $\begin{array}{l}5 \mid 46 \ldots 6099 \\
108068 \mid \ldots 1081634\end{array}$ & $\begin{array}{l}954 \\
954\end{array}$ & 95,60 & $50.0,60$ & 72,60 \\
\hline $\begin{array}{l}\text { ureD3 } \\
\text { ureD4 }\end{array}$ & $\begin{array}{l}\text { TTGTTAACCCCCAA } \\
\text { AGAGCATCAT } \\
\text { CTGCCGGATTCCCT } \\
\text { TCGCCATAG }\end{array}$ & ureD-yut & $\begin{array}{l}\text { DQ350880 } \\
\text { AM286415 }\end{array}$ & $\begin{array}{l}5884 \ldots 6416 \\
\mid 081419 \ldots 1081950\end{array}$ & $\begin{array}{l}533 \\
532\end{array}$ & 95,60 & $58.0,60$ & 72,60 \\
\hline $\begin{array}{l}\text { Yut I } \\
\text { Yut2 }\end{array}$ & $\begin{array}{l}\text { CGCGGCTGTGCTCA } \\
\text { AGTC } \\
\text { GTGCTGGCATCACA } \\
\text { TCTTTATTAGG }\end{array}$ & yut & AM2864I5 & $108|85| \ldots \mid 082745$ & 895 & 95,60 & $50.0,60$ & 72,60 \\
\hline
\end{tabular}

The primer details and the PCR conditions used are given.

DQ350880: Y. enterocolitica IP27403 (bioserovar IA/O:6,30); AM2864I5: Y. enterocolitica 808I (bioserovar IB/O:8); ZI88665: Y. enterocolitica 647I/76 (bioserovar 4/O:3)

Nucleotides sequences in bold are different in biovar IA strain (DQ350880)

*PCRs were performed with initial denaturation step of $94^{\circ} \mathrm{C}$ for $10 \mathrm{~min}, 30$ cycles each of denaturation (Den), annealing (Ann) and extension (Ext) as indicated and a final extension of $10 \mathrm{~min}$ at $72^{\circ} \mathrm{C}$

\section{Urease assay}

Urease activity in the cell extract was assayed by measuring release of ammonia from urea in the phenol-hypochlorite assay [32]. Briefly, extract containing $2 \mu \mathrm{g}$ of protein was added to $100 \mathrm{mM}$ citrate buffer ( $\mathrm{pH} 5.5$ ) containing 50 $\mathrm{mM}$ urea in $200 \mu \mathrm{l}$ of final volume. The mixture was incubated at $37^{\circ} \mathrm{C}$ for $15 \mathrm{~min}$. A similar volume of the extract boiled for 10 min served as negative control. The reaction was terminated by the addition of $1.5 \mathrm{ml}$ of solution containing $1 \%$ phenol and $0.005 \%$ sodium nitroprusside; this was followed by the addition of $1.5 \mathrm{ml}$ solution containing $0.5 \%(\mathrm{w} / \mathrm{v}) \mathrm{NaOH}$ and $0.044 \%(\mathrm{v} / \mathrm{v}) \mathrm{NaClO}$, and the contents were mixed well. Following incubation at $37^{\circ} \mathrm{C}$ for $30 \mathrm{~min}$, the absorbance was measured at $625 \mathrm{~nm}$

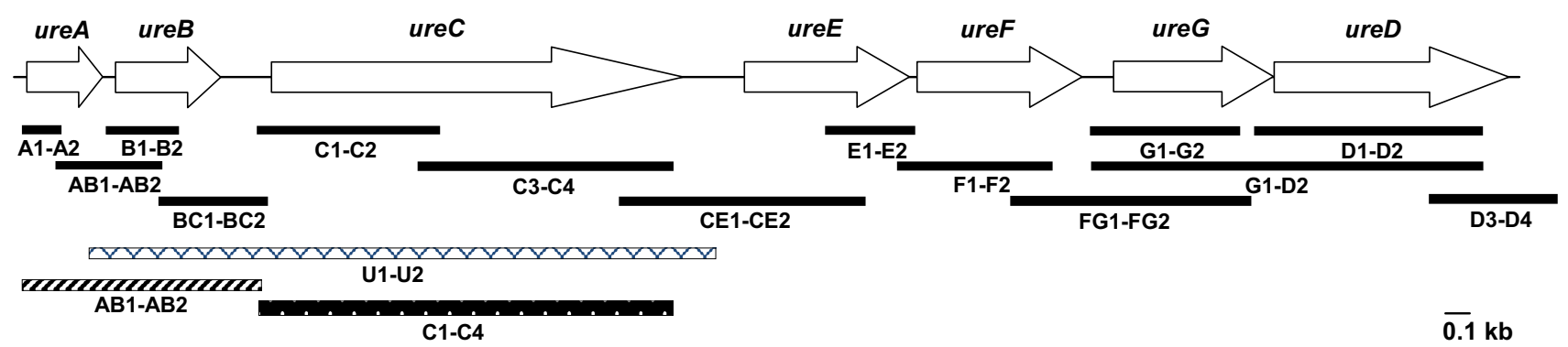

Figure I

Organization of ure gene cluster of $Y$. enterocolitica biovar I A. Primers used for amplification of structural and accessory genes, and the intergenic regions thereof are indicated. 
using a spectrophotometer (UV-1700 Pharmaspec; Shimadzu Scientific Instruments Inc., Columbia, Md.). Assays were carried out in triplicate and the amount of the ammonia released per minute was determined. The quantity of ammonia (in nmol) released was calculated from the calibration curve obtained from appropriate dilutions of freshly prepared $\mathrm{NH}_{4} \mathrm{Cl}$ solution, which was determined to be linear between $20-500 \mathrm{nmol}$. Data are presented as specific activity of urease, defined as $\mu \mathrm{mol}$ of $\mathrm{NH}_{3} / \mathrm{min} / \mathrm{mg}$ of protein. Stated values are the mean \pm standard deviation of triplicate determinations.

\section{Biochemical characterization}

The optimum $\mathrm{pH}$ for urease was determined by measuring activity at $\mathrm{pH} 1.5$ to 7.5 . The assays were carried out in $20 \mathrm{mM}$ sodium phosphate (for $\mathrm{pH}$ 1.5, 2.5, 5.5, 6.0, 6.5, 7.0 and 7.5 ) and $100 \mathrm{mM}$ citrate (for $\mathrm{pH} 3.0,3.5,4.0$ and 5.5) buffers. The optimum temperature for urease was determined by incubating the extract containing enzyme with substrate at different temperatures $\left(18-75^{\circ} \mathrm{C}\right)$ in the phenol-hypochlorite assay described above. The kinetic data $\left(\mathrm{K}_{\mathrm{m}}\right.$ and $\left.\mathrm{V}_{\text {max }}\right)$ of urease were calculated from Lineweaver-Burk plot of the initial rate of hydrolysis of urea in citrate buffer $(100 \mathrm{mM}, \mathrm{pH} 5.5)$. To determine the effect of growth temperature and growth phase on urease activity, extracts were prepared from cells grown in shaking at $28^{\circ} \mathrm{C}$ and $37^{\circ} \mathrm{C}$ in $\mathrm{LB}$ medium for different time intervals. To determine the effect of urea and nickel on production of urease, medium was supplemented with urea $\left(16.7 \mathrm{mM}\right.$ ) or $\mathrm{NiCl}_{2}$ (up to $200 \mu \mathrm{M}$ ).

\section{Native and SDS PAGE}

Cell-free extracts from different biovars of $Y$. enterocolitica were electrophoresed on non-denaturing polyacrylamide gel [33]. Briefly, extract containing $c a .100 \mu \mathrm{g}$ of protein was mixed with $1 \times$ tracking dye and loaded on $5 \%$ resolving gel in $380 \mathrm{mM}$ Tris- $\mathrm{HCl}$ (pH 8.8) with $4 \%$ stacking gel in $63 \mathrm{mM}$ Tris-HCl (pH 6.8) in a mini-Protein III apparatus (Bio-Rad). Samples were electrophoresed with TrisGlycine (pH 8.4) as the running buffer at $70 \mathrm{~V}$ for $2 \mathrm{~h}$ at $4{ }^{\circ} \mathrm{C}$. The gel was removed and equilibrated with 5-10 changes of solution containing $0.02 \%$ cresol red and $0.1 \%$ EDTA until the entire gel turned yellow. After draining the solution, gel was flooded with $1.5 \%(\mathrm{w} / \mathrm{v})$ solution of urea. The pink bands of urease were recorded by scanning (UMAX Astra 3600). Urease from jack bean (Sigma) was used as the marker.

SDS-PAGE was performed as per standard protocol [34]. Briefly, extract containing $25 \mu \mathrm{g}$ of protein was boiled in reducing Laemmli sample buffer and separated on $12 \%$ polyacrylamide gel.

\section{Isoelectric focusing (IEF)}

IEF of the cell extract was carried out in $6 \%$ polyacrylamide gel containing 2\% ampholyte of $\mathrm{pH}$ 3-10 (Biolyte Ampholyte, Bio-Rad). 3-5 $\mu \mathrm{l}$ of extract containing $c a$. 20$25 \mu \mathrm{g}$ of protein was loaded on the gel and focused at $4{ }^{\circ} \mathrm{C}$ using a Mini IEF cell (Bio-Rad) according to the manufacturer's instructions. After focusing, the gel was equilibrated with a solution containing $0.02 \%$ cresol red and $0.1 \%$ EDTA. Urease bands were visualized by superimposing the gel with Whatman No. 1 filter paper presaturated with cresol red-EDTA solution containing 1.5\% urea. Urease appeared as pink band against a yellow background. Broad range IEF standard with pI 4.45-9.6 (Bio-Rad) was used as the pI marker to determine the isoelectric point of the urease.

\section{Survival of $\mathbf{Y}$. enterocolitica in acidic $\mathrm{pH}$ in vitro}

The in vitro survival of $Y$. enterocolitica was performed by slight modification of the method reported earlier [35]. Briefly, ten microlitre of the bacterial suspension was added to $1 \mathrm{ml}$ of $20 \mathrm{mM}$ sodium phosphate (for $\mathrm{pH} 2.5$ and 7.0) or $100 \mathrm{mM}$ citrate (for $\mathrm{pH} 4.0$ ) buffer with or without $3.4 \mathrm{mM}$ urea in $0.6 \% \mathrm{NaCl}$, and prewarmed to $37^{\circ} \mathrm{C}$ to give an initial count of $c a .7 .0 \log _{10} \mathrm{CFU} / \mathrm{ml}$. The contents were mixed and incubated with shaking at $37^{\circ} \mathrm{C}$ for $2 \mathrm{~h}$. At the end of the incubation, samples were removed and diluted serially in $20 \mathrm{mM}$ sodium phosphate buffer (pH 7.0). $0.1 \mathrm{ml}$ of an appropriate dilution was plated on LB agar to determine CFU/ml. At conclusion of each assay, the $\mathrm{pH}$ of the buffer was recorded. All assays were repeated at least thrice on separate occasions.

\section{Statistical analysis}

The mean and the standard deviation for each data set were calculated using Microsoft Excel 2003 software (Microsoft Corporation, Redmond, Wash.). Statistical significance was calculated using unpaired $t$ test (Sigma Stat version 3.5). $p$ value $<0.05$ was considered significant.

\section{Nucleotide sequence accession number}

The nucleotide sequence data of ure gene complex and the yut gene reported in this paper have been deposited in GenBank database under accession numbers DQ350880 and EU527335 respectively.

\section{Results \\ Characterization of urease genes}

Primers $\mathrm{U} 1$ and $\mathrm{U} 2$ were designed to amplify the ure structural (ureA, ureB, ure C) genes of $Y$. enterocolitica. Although amplification was obtained with biovar $1 \mathrm{~B}, 2$ and 4 strains, these primers did not consistently amplify the ure structural genes of biovar 1A strains. Thus, new primers were designed to amplify each of the ure structural and accessory (ureE, ureF, ure $G$, ureD) genes separately, and the intergenic regions so as to encompass the entire urease 
gene cluster of biovar 1A strain. Amplicons of expected sizes were obtained for all genes except $u r e B$ and the intergenic regions namely ureA-ureB, ureB-ureC and ureC-ureE (Table 1). The sequences thus obtained were analyzed for homology with sequences available in databases, edited and combined to obtain 7,180 bp sequence of ure gene cluster of biovar 1A strain (See Additional file 1 for ure gene cluster sequence).

Seven ORFs were identified in the ure gene cluster of $Y$. enterocolitica biovar $1 \mathrm{~A}$ strain and designated as ure A, ureB, ure $C$, ureE, ureF, ureG and ureD (Fig. 1) as in the ure gene complex of $Y$. enterocolitica 8081 (biovar 1B, accession number AM286415). As with Y. enterocolitica 8081, yut gene which encodes a urea transport protein was present downstream of the ure gene cluster. All ORFs had ATG as the start codon except ure $G$ where the start codon was GTG. These ORFs were preceded by ribosome-binding consensus sequence. Although ure gene cluster of biovar $1 \mathrm{~A}$ strain was broadly similar to that of biovar $1 \mathrm{~B}$ and bio- var 4 strains, differences were identified. These were smaller ureB gene and ureA-ureB intergenic region and larger ureB-ureC and ureC-ureE intergenic regions in biovar 1A strain (Table 2). The size of ureB gene of Y. enterocolitica biovar 1A was identical to ureB of $Y$. aldovae, $Y$. bercovieri, $Y$. intermedia, $Y$. mollaretii and exhibited higher nucleotide sequence identity to these species than to $Y$. enterocolitica biovar $1 \mathrm{~B}$ or 4 . The stop codon of ure $\mathrm{G}$ overlapped with the start codon of ureD gene. The $\mathrm{G}+\mathrm{C}$ content of the urease gene cluster was $49.76 \%$ which was typical of Y. enterocolitica with G $+\mathrm{C}$ content of $47.27 \%$.

The comparison of $Y$. enterocolitica biovar 1A ure genes and the deduced amino acid sequences with that of Yersinia spp. and other bacteria are given in Tables 2 and 3 respectively. Besides Yersinia species, the homologies of ure genes (upto $76 \%$ identity) and their deduced amino acid sequences (upto $86 \%$ identity and $95 \%$ similarity) were significant with ureases from Photorhabdus luminescens and Edwardsiella ictaluri. The UreA, UreC and UreG

Table 2: Urease structural and accessory genes and the intergenic regions thereof, in Y. enterocolitica biovar IA.

\begin{tabular}{|c|c|c|c|c|c|c|c|c|c|}
\hline \multirow[t]{2}{*}{ Gene/Intergene } & \multirow[t]{2}{*}{ YeIA } & \multicolumn{8}{|c|}{ Size (in bp) and \% identity } \\
\hline & & YeO8 & $\mathrm{YeO3}$ & Yers & Yps & Ype & $\mathbf{P I}$ & Ei & $\mathbf{K a}$ \\
\hline \multicolumn{10}{|l|}{ Structural } \\
\hline ureA & 303 & $\begin{array}{l}303 \\
98\end{array}$ & $\begin{array}{l}303 \\
98\end{array}$ & $\begin{array}{l}303 \\
89-96\end{array}$ & $\begin{array}{l}303 \\
91\end{array}$ & $\begin{array}{l}303 \\
91\end{array}$ & $\begin{array}{l}303 \\
77\end{array}$ & $\begin{array}{l}303 \\
76\end{array}$ & $\begin{array}{l}303 \\
63\end{array}$ \\
\hline ure $B$ & 435 & $\begin{array}{l}495 \\
83\end{array}$ & $\begin{array}{l}495 \\
83\end{array}$ & $\begin{array}{l}435-495^{*} \\
\mathbf{7 8 - 8 9}\end{array}$ & $\begin{array}{l}435 / 477 \\
74-82\end{array}$ & $\begin{array}{l}435 / 477 / 528 \\
67-81\end{array}$ & $\begin{array}{l}390 \\
63\end{array}$ & $\begin{array}{l}423 \\
62\end{array}$ & $\begin{array}{l}321 \\
48\end{array}$ \\
\hline ureC & 1719 & $\begin{array}{l}1719 \\
96\end{array}$ & $\begin{array}{l}1722 \\
94\end{array}$ & $\begin{array}{l}1719 \\
87-91\end{array}$ & $\begin{array}{l}1719 \\
86\end{array}$ & $\begin{array}{l}1719 \\
82-86\end{array}$ & $\begin{array}{l}1716 \\
75\end{array}$ & $\begin{array}{l}1719 \\
76\end{array}$ & $\begin{array}{l}1704 \\
61\end{array}$ \\
\hline \multicolumn{10}{|l|}{ Accessory } \\
\hline ureE & 687 & $\begin{array}{l}792 / 693 \\
85 / 97\end{array}$ & NA & $\begin{array}{l}68 \mid-720 \\
83-91\end{array}$ & $\begin{array}{l}696 \\
82\end{array}$ & $\begin{array}{l}\text { 696/705 } \\
\mathbf{8 0 - 8 2}\end{array}$ & $\begin{array}{l}597 \\
59\end{array}$ & $\begin{array}{l}678 \\
\mathbf{5 8}\end{array}$ & $\begin{array}{l}477 \\
44\end{array}$ \\
\hline ureF & 687 & $\begin{array}{l}687 \\
98\end{array}$ & NA & $\begin{array}{l}687 \\
85-90\end{array}$ & $\begin{array}{l}687 \\
85-86\end{array}$ & $\begin{array}{l}687 \\
86\end{array}$ & $\begin{array}{l}687 \\
66\end{array}$ & $\begin{array}{l}705 \\
\mathbf{6 5}\end{array}$ & $\begin{array}{l}675 \\
48\end{array}$ \\
\hline ureG & 666 & $\begin{array}{l}666 / 606 \\
99 / 90\end{array}$ & NA & $\begin{array}{l}666 \\
88-92\end{array}$ & $\begin{array}{l}663 \\
84\end{array}$ & $\begin{array}{l}663 \\
85\end{array}$ & $\begin{array}{l}636 \\
78\end{array}$ & $\begin{array}{l}630 \\
73\end{array}$ & $\begin{array}{l}618 \\
59\end{array}$ \\
\hline ureD & 984 & $\begin{array}{l}978 / 984 \\
96 / 97\end{array}$ & NA & $\begin{array}{l}966-984 \\
\mathbf{8 4 - 9 0}\end{array}$ & $\begin{array}{l}966 \\
81\end{array}$ & $\begin{array}{l}834 / 964 / 967 \\
71-82\end{array}$ & $\begin{array}{l}966 \\
64\end{array}$ & $\begin{array}{l}963 \\
62\end{array}$ & - \\
\hline \multicolumn{10}{|l|}{ Intergenic region } \\
\hline ure $A B$ & 54 & 53 & 53 & $53-65$ & $10 / 52$ & $0 / 10 / 52$ & 91 & 46 & 9 \\
\hline ure $B C$ & 202 & 164 & 164 & $87-97 / 201-202 *$ & 89 & 89 & 67 & 42 & 0 \\
\hline ureCE & 236 & $74 / 173$ & NA & $133-204$ & $294 / 295$ & $286 / 295$ & 74 & 57 & 9 \\
\hline ureEF & 21 & 21 & NA & $20-24$ & 21 & 21 & 0 & 0 & 1 \\
\hline ureFG & 117 & II7/177 & NA & $58-102$ & $125 / 126$ & 126 & 52 & 14 & 8 \\
\hline ureGD & 0 & $\mathrm{I} / 0$ & NA & 0 & 0 & 0 & 0 & 6 & - \\
\hline
\end{tabular}

Comparison with different Yersinia spp. and other bacteria.

The abbreviations correspond to following species with accession number(s) in parentheses. YeIA: Y. enterocolitica bioserovar IA/O:6,30 (DQ350880); YeO8: Y. enterocolitica bioserovar IB/O:8 (L24I0I, AM2864I5); YeO3: Y. enterocolitica bioserovar 4/O:3 (Z18865); Yers included Y. aldovae (AY363680), Y. bercovieri (AY36368I), Y. frederiksenii (AY363682), Y. intermedia (AY363683), Y. kristensenii (AY363684), Y. mollaretii (AY363685), Y. rohdei (AY363686); Yps: Y. pseudotuberculosis (U40842; CP000720; CP000950; BX936398); Ype: Y. pestis (CP00090I, CP000308, AL590842, AE017042, CP000305, CP000668, AF095636); PI: Photorhabdus luminescens (BX57I866); Ei: Edwardsiella ictaluri (AY607844); Ka: Klebsiella aerogenes $(\underline{\mathrm{M} 36068})$

$\%$ identity is indicated in bold

0 indicates that the intergenic region had overlapping stop and start codons

*ureB gene size was 435 bp (Y. aldovae, Y. bercovieri, Y. intermedia, and Y. mollaretii), 44I bp (Y. rohdei), 468 bp (Y. frederiksenii) and 495 bp (Y.

kristensenii); ureBC intergenic region of 20I-202 bp was present in $Y$. aldovae and $Y$. intermedia 
Table 3: Urease structural and accessory proteins of $Y$. enterocolitica biovar IA (Ye IA).

\begin{tabular}{|c|c|c|c|c|c|c|c|c|c|c|c|c|}
\hline & \multirow[t]{2}{*}{ Gene } & \multirow{2}{*}{$\begin{array}{c}\text { Gene } \\
\text { product } \\
\text { (aa) }\end{array}$} & \multirow{2}{*}{$\begin{array}{l}\text { Mol. mass } \\
(\mathrm{Da})^{*}\end{array}$} & \multirow[t]{2}{*}{$\mathbf{p l}^{*}$} & \multicolumn{8}{|c|}{$\%$ identity $/ \%$ similarity } \\
\hline & & & & & YeO8 & $\mathrm{YeO3}$ & Yers & Yps & Ype & PI & Ei & $\mathbf{K a}$ \\
\hline \multicolumn{13}{|c|}{$\begin{array}{l}\text { Structural } \\
\text { subunits }\end{array}$} \\
\hline UreA & ureA & 100 & 11,048 & 5.29 & $99-100$ & 100 & $97-100 / 100$ & 100 & 100 & $79 / 95$ & $86 / 95$ & $60 / 82$ \\
\hline UreB & ure $B$ & 144 & 15,854 & 9.06 & $\begin{array}{l}84-85 / 85- \\
86\end{array}$ & $85 / 86$ & $\begin{array}{l}84-99 / 85- \\
99\end{array}$ & $\begin{array}{l}86-94 / 88- \\
97\end{array}$ & $\begin{array}{l}78-94 / 79- \\
97\end{array}$ & $60 / 72$ & $61 / 73$ & $36 / 47$ \\
\hline UreC & ureC & 572 & 61,026 & 5.64 & $99 / 100$ & $95 / 97$ & $\begin{array}{l}97-99 / 99- \\
100\end{array}$ & $97 / 99$ & $\begin{array}{l}93-97 / 95- \\
99\end{array}$ & $83 / 91$ & $86 / 94$ & $58 / 73$ \\
\hline \multicolumn{13}{|c|}{$\begin{array}{l}\text { Accessory } \\
\text { proteins }\end{array}$} \\
\hline UreE & ureE & 228 & 25,507 & 6.35 & $86-99$ & NA & $\begin{array}{l}91-95 / 95- \\
97\end{array}$ & $94 / 97$ & $\begin{array}{l}92-93 / 96- \\
97\end{array}$ & $55 / 69$ & $50 / 70$ & $27 / 39$ \\
\hline UreF & ureF & 228 & 25,040 & 6.41 & 100 & NA & $\begin{array}{l}96-99 / 97- \\
100\end{array}$ & $98 / 99$ & $97-98 / 99$ & $67 / 76$ & $65 / 83$ & $22 / 43$ \\
\hline UreG & ureG & 221 & 24,181 & 4.94 & $91-100$ & NA & $\begin{array}{l}98-100 / 99- \\
100\end{array}$ & $96 / 97$ & $96 / 97$ & $86 / 91$ & $86 / 91$ & $54 / 71$ \\
\hline UreD & ure $D$ & 327 & 36,592 & 6.61 & $\begin{array}{l}93-98 / 95- \\
99\end{array}$ & NA & $\begin{array}{l}91-98 / 95- \\
99\end{array}$ & $93 / 96$ & FS & $64 / 77$ & $59 / 71$ & - \\
\hline
\end{tabular}

Comparison with different Yersinia spp. and other bacteria.

The abbreviations correspond to following species with protein accession numbers for UreA, UreB, UreC, UreE, UreF, UreG and UreD in parentheses: YelA: Y. enterocolitica biovar IA (ABC74582-ABC74585; ACA51855-ACA5I857); YeO8: Y. enterocolitica O8 biovar IB (AAA50994AAA51000, CALI 1049-CALI 1055); YeO3: Y. enterocolitica O3 biovar 4 (CAA793 I4-AA79320); Yers included Y. aldovae (AR I 5084-AARI 5090); Y. bercovieri (AARI5092-AAR I5098); Y. frederiksenii (AARI5I00-AARI5I06); Y. intermedia (AAR I5I08-AAR I5II4); Y. kristensenii (AAR I5II7AARI5I23); Y. mollaretii (AARI5I26-AARI5I32); Y. rohdei (AARI5I35-AARI5I4I); Yps: Y. pseudotuberculosis (CAH22I82-CAH22I 76, AAA87852AAA87858, ACA67429-ACA67435); Ype: Y. pestis (ABG I4357-ABG I 4363; CAL2I 284-CAL2I 289; AAS62666-AAS6267I; AAM848I2-AAM848I7; ABG 17479-ABG 17485; ABP39996-ABP39990; AAC78632-AAC78638); PI: Photorhabdus luminescens (CAEI4464-CAEI4470); Ei: Edwardsiella ictaluri (ABD93708-ABD93706, AAT42448-AAT42445); Ka: Klebsiella aerogenes (AAA25I49-AAA25I54); NA: Not available; FS: frameshift mutation

* Theoretical molecular mass and pl were determined with DNASTAR

proteins were most conserved among Yersinia spp. The estimated molecular weights, in $\mathrm{Da}$, of the protein subunits were 11,048 (UreA), 15,854 (UreB), 61,026 (UreC), 25,507 (UreE), 25,040 (UreF), 24,181 (UreG) and 36,592 (UreD) (Table 3).

Phylogenetic analysis of urease structural and accessory proteins of $Y$. enterocolitica biovar 1A showed clustering with members of gamma-proteobacteria such as $P$. luminescens and E. ictaluri along with Yersinia spp. (See Additional files 2 and 3 ). These protein sequences were also related closely to members of alpha-proteobacteria like Methylobacterium chloromethanicum, M. extorquens, M. populi and Brucella spp. but were related distantly to other members of gamma-proteobacteria like Klebsiella aerogenes, P. mirabilis and Escherichia coli.

\section{PCR-RFLP of ure genes}

The regions constituting the structural genes namely ure $A B$ and ure $C$ were amplified in several $Y$. enterocolitica biovar 1A strains using primer pairs $\mathrm{AB} 3-\mathrm{AB} 4$ and $\mathrm{C} 1-\mathrm{C} 4$ respectively. Restriction digestion of ure $A B$ region with HaeIII and Sau96I resulted in almost identical patterns among all biovar 1A strains (See Additional file 4). But, differences were clearly evident in restriction profiles of ureC digested with RsaI and Sau96I (Fig. 2). With RsaI, strains belonging to clonal group A exhibited profile different from that of clonal group B strains. Thus, it may be inferred that sequence of urease gene in clonal group A strains is different from that of clonal group B strains.

The HaeIII and Sau96I restriction profiles of ureAB of biovar 1B, 2 and 4 strains were distinct from that of biovar $1 \mathrm{~A}$ strains (See Additional file 4). As with ureAB, restriction patterns of ure $C$ for these biovars were also quite distinct from biovar 1A strains (data not shown).

\section{Biochemical characterization}

The crude extract of urease of $Y$. enterocolitica biovar 1A strain was active over a $\mathrm{pH}$ range of 4.0-7.0. The maximum activity was observed at pH 5.5 (Fig. 3a). The enzyme was quite heat-stable as urease activity was recorded up to $65^{\circ} \mathrm{C}$ but decreased progressively at higher temperature (Fig. 3b). The optimum temperature for urease activity was $65^{\circ} \mathrm{C}$ (Fig. 3b). The urease exhibited Michaelis-Menten kinetics with $\mathrm{K}_{\mathrm{m}}$ and $\mathrm{V}_{\max }$ of $1.74 \pm 0.4$ $\mathrm{mM}$ urea and $7.29 \pm 0.42 \mu \mathrm{mol}$ of ammonia released/ $\mathrm{min} / \mathrm{mg}$ of protein respectively (data not shown). 

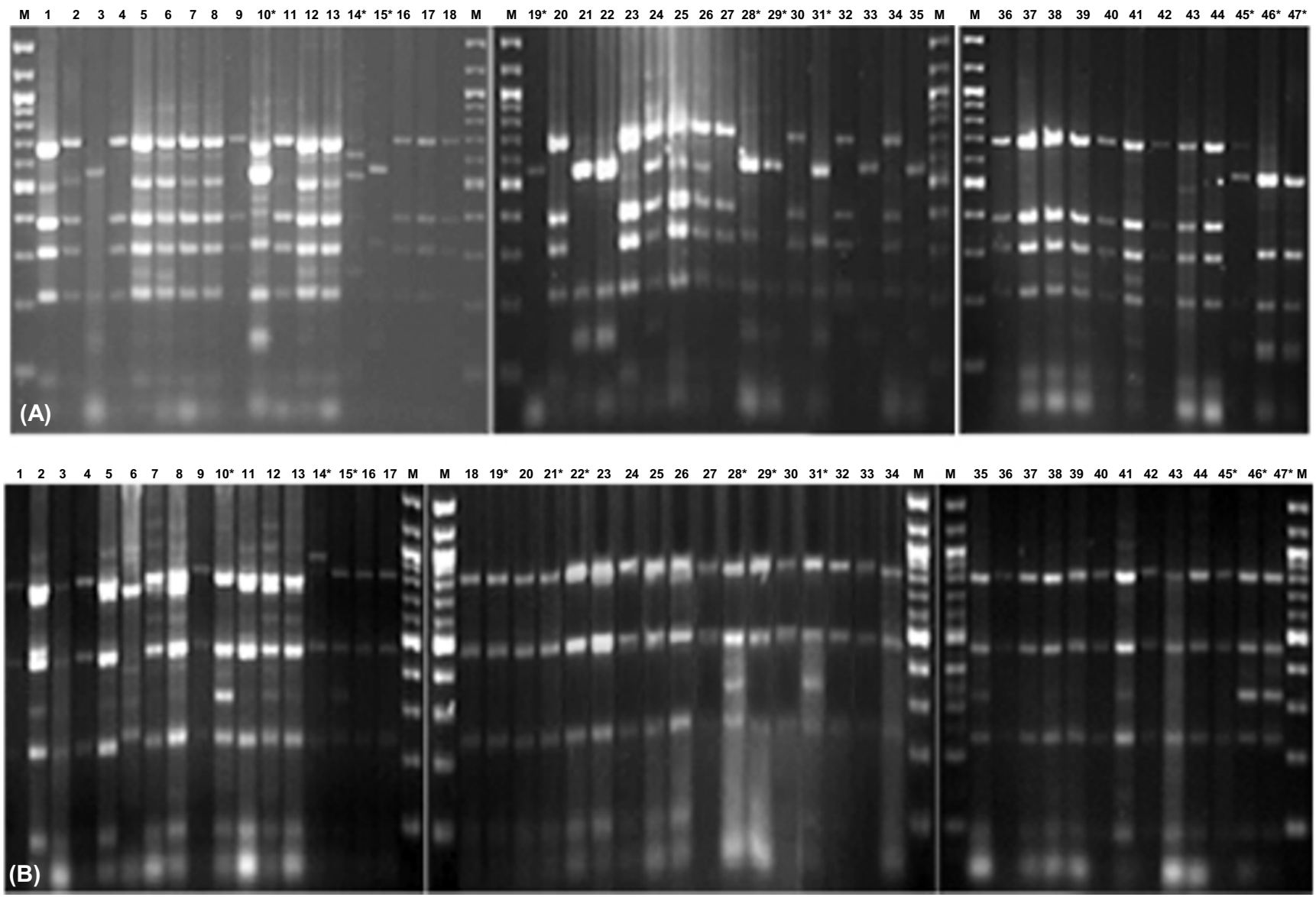

\section{Figure 2}

PCR-RFLP of ureC. PCR-RFLP of ureC of $Y$. enterocolitica biovar IA strains amplified with primers ureCI-ureC4, and restriction digested using (A) Rsal and (B) Sau96I enzymes. Lanes I: IP27360, 2: IP27362, 3: IP27364, 4: IP27365, 5: IP263 I0, 6: IP263 I I, 7: IP263 I 2, 8: IP263 I 5, 9: IP27403, I0: IP27407, I I: IP27429, I2: IP27433, I3: IP27434, I4: IP2626I, I5: IP26305, I6: EI 28I580, I7: IP263 I6, I8: EI 28I550, I9: IP26I52, 20: P346, 2 I: P354, 22: P386, 23: P472, 24: IP27404, 25: IP27406, 26: IP27430, 27: IP27432, 28: IP27484, 29: IP26I47, 30: IP26I 48, 3I: EI 28I600, 32: IP27385, 33: IP27386, 34: IP27388, 35: IP27485, 36: STM 126, 37: 8660/90 STM 484, 38: 03 I0/90, 39: ST5 NF-O, 40: IP27879, 4I: IP27873, 42: IP27950, 43: IP27985, 44: IP24I 2I, 45: IP27648, 46: IP272 I0, 47: IP27I49, M: Molecular mass marker (100 bp ladder, New England BioLabs). * Strains belonging to clonal group $B$ are shown in lanes 10, 14, I5, 19, 21, 22, 28, 29, 31, 45, 46 and 47. Clonal group A strains are in other lanes. For clonal groups refer to [22].

Y. enterocolitica biovar $1 \mathrm{~A}$ grown at $28^{\circ} \mathrm{C}$ (optimum temperature for growth) exhibited higher urease activity than that grown at $37^{\circ} \mathrm{C}$ (Fig. 3c). Irrespective of the growth temperature, stationary phase cells showed higher activity (Fig. 3c). The supplementation of growth medium (Luria broth) with $16.7 \mathrm{mM}$ urea did not show significant difference in urease activity. However, supplementation with nickel chloride resulted in ca. 10-fold increase in the activity. $1 \mu \mathrm{M} \mathrm{NiCl}_{2}$ was sufficient to induce urease activity as no significant increase in the activity was observed with further increase in concentration up to $200 \mu \mathrm{M}$ (See Additional file 5).
On native PAGE, urease was observed as two bands with the major band having molecular weight $>545 \mathrm{kDa}$ and a slowly-developing band above it (Fig. 4). The electrophoretic mobility of urease of $Y$. enterocolitica biovar $1 \mathrm{~A}$ strain was shown to be different from that of biovar 1B, 2 and 4 strains though similar to the $Y$. intermedia urease. The isoelectric point of the crude extract urease was 5.2.

\section{Survival of $\mathbf{Y}$. enterocolitica in vitro}

The ability of $Y$. enterocolitica biovar 1A strain to survive at $\mathrm{pH} 2.5,4.0$ and 7.0 in vitro was investigated. Strains belonging to other biovars were also studied concurrently. 

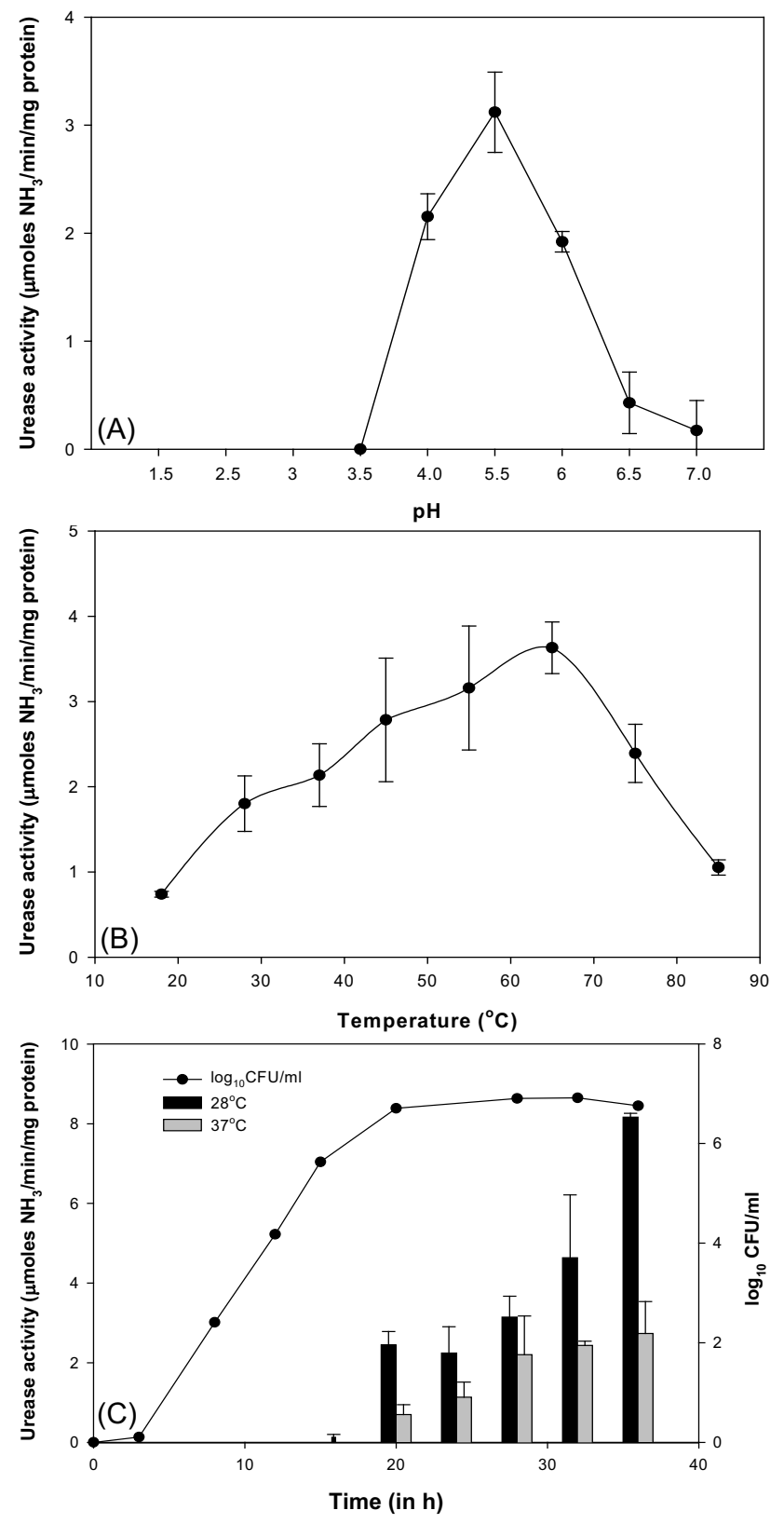

Figure 3

Biochemical characterization of $Y$. enterocolitica biovar I A urease. (a) optimal $\mathrm{pH}$ for urease activity (b) effect of temperature on urease activity and (c) effect of growth phase and growth temperature on urease production; growth curve of biovar IA strain grown at $28^{\circ} \mathrm{C}$ is also shown. Data points represent mean of triplicate determinations. The error bars indicate standard deviation.

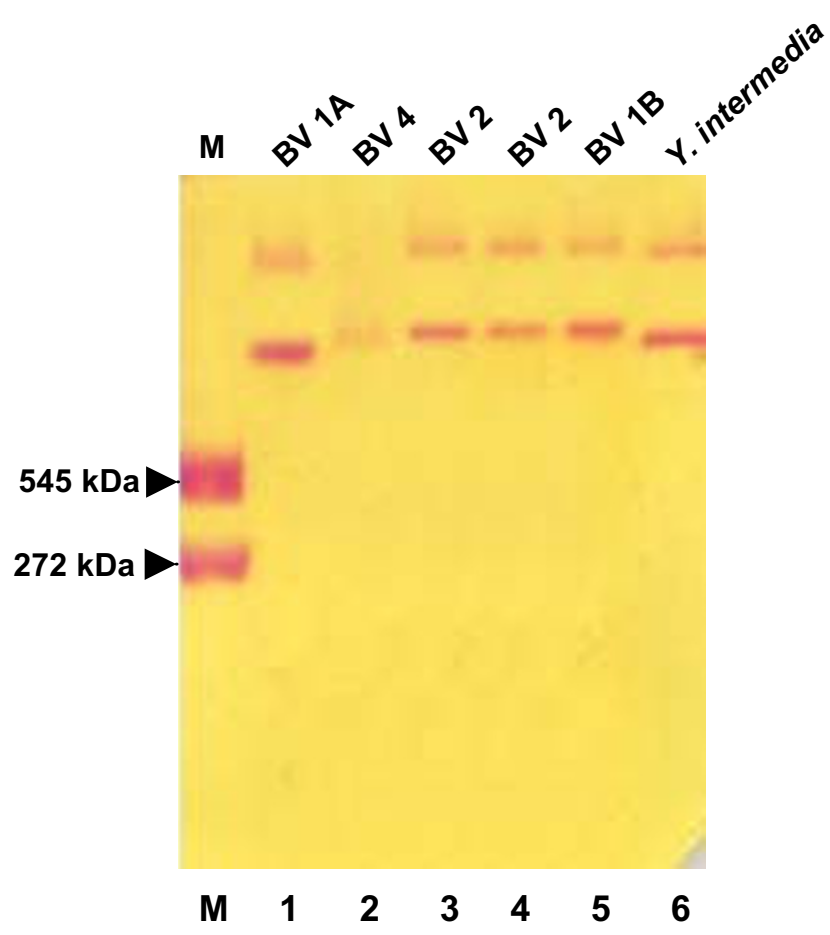

Figure 4

Non-denaturing PAGE showing urease activity of Yersinia spp. Lane I: Y. enterocolitica IP27403 (IA/O:6,30); lane 2: Y. enterocolitica IPI 34 (4/O:3); lane 3: Y. enterocolitica IP26329 (2/O:9); lane 4: Y. enterocolitica IP26249 (2/O:5,27); lane 5: Y. enterocolitica 808I (IB/O:8); lane 6: Y. intermedia IP27478 (serotype O:7,8-8); M: Jack bean urease [272 kDa (trimer) and 545 kDa (hexamer); BV: Biovar.

The biovar 1A strain survived at $\mathrm{pH} 4.0$ and 7.0 for $2 \mathrm{~h}$ without significant differences in their viable counts (Fig. 5). However, no viable cells were recovered after $2 \mathrm{~h}$ at $\mathrm{pH}$ 2.5. In fact, the decrease in the viable counts at this $\mathrm{pH}$ was evident even within 5 min of incubation. The addition of $3.4 \mathrm{mM}$ urea at $\mathrm{pH} 2.5$ was sufficient to increase the survival of $Y$. enterocolitica biovar 1A equivalent to that observed at $\mathrm{pH} 4.0$ and 7.0. Similar results were observed for other biovars also. The $\mathrm{pH}$ of the assay medium at the end of experiment was same as that at the start, suggesting that increased survival of $Y$. enterocolitica was not due to any significant change in the $\mathrm{pH}$.

\section{Discussion}

The ure gene cluster of $Y$. enterocolitica biovar 1A strain included three structural (ureA, ureB, ureC) and four (ureE, ureF, ure $G$, ureD) accessory genes. The yut gene, which is required for transport of urea was present downstream of this cluster. Thus, the organization (ureABCEFGD) of ure gene cluster in $Y$. enterocolitica biovar $1 \mathrm{~A}$ strain was similar to that reported for $Y$. enterocolitica biovar 1B, P. luminescens and E. ictaluri $[23,36,37]$. Similar organization has 


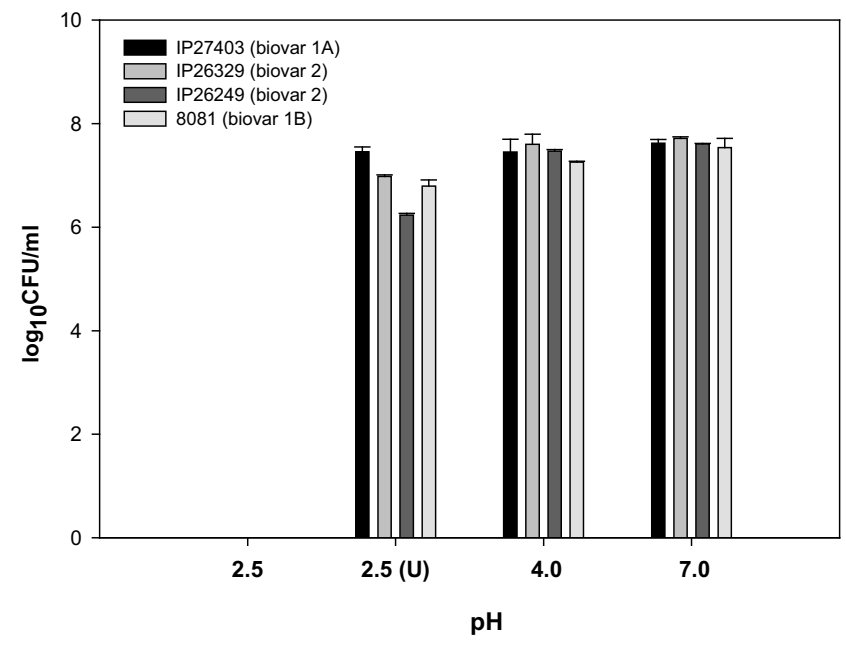

Figure 5

Survival of $Y$. enterocolitica in vitro at different $\mathrm{pH}$. Number of bacterial cells $\left(\log _{10} \mathrm{CFU} / \mathrm{ml}\right)$ of $Y$. enterocolitica after incubation for $2 \mathrm{~h}$ at $\mathrm{pH} 2.5,4.0$ and 7.0 in the absence and presence $(U)$ of $3.4 \mathrm{mM}$ urea. The values are mean of three independent observations. The error bars indicate standard deviation.

been reported for other species such as Streptococcus salivarius, Synechococcus sp. WH7805, and B. abortus ure-2 operon $[19,38,39]$. However, important differences were observed compared to urease genes of $Y$. enterocolitica biovar 1B and biovar 4 strains. These included differences in the size of ureB gene and the intergenic regions. Also, the restriction profiles of ure structural genes of biovar $1 \mathrm{~A}$ strains were different from that of biovars $1 \mathrm{~B}, 2$ and 4 . These observations indicated that RFLP of urease genes may be used to study the epidemiology of Y. enterocolitica.

The amino acid residues in the urease structural proteins namely UreA ( $\gamma$ subunit), UreB ( $\beta$ subunit) and UreC ( $\alpha$ subunit) that are reported to have functional significance in $K$. aerogenes urease [40] were also conserved in Y. enterocolitica biovar 1A. The crystallographic [41] and genetic [40] analysis of $K$. aerogenes urease has shown that four histidine residues (His-134,-136, -246 and -272), an aspartate (Asp-360) and a carbamylated lysine (Lys-217) of UreC are involved in nickel metallocenter binding. All these amino acids were conserved at positions His-139, 141, -251, -277; Asp-365 and Lys-222 in UreC of Y. enterocolitica biovar 1A. Histidine residues in the $\alpha$-subunit of $K$. aerogenes shown to be important for substrate binding (His-219) and catalysis (His-320) are present at positions 224 and 325 in $\alpha$-subunit of biovar 1A [40]. The urease active-site consensus sequence (MVCHHLD) [42] deviated by two residues (MVCHNLN) in biovar 1A strain. Amino acid residues with functional significance including His-97 (UreA) and His-39, -41 (UreB) [40] were also conserved in relative positions in $Y$. enterocolitica biovar 1A. The conservation of amino acids in $Y$. enterocolitica biovar 1A urease involved in coordination of nickel at active site, substrate binding and catalysis as seen in $K$. aerogenes urease, suggested similar quaternary structure of the two enzymes. UreE consisted of histidine-rich motif at carboxy terminus as in UreE of $K$. aerogenes, B. abortus, Actinobacillus pleuropneumoniae, E. ictaluri and Synechococcus $[19,36,39,43,44]$. A P-loop motif (GPVGSGKT), which contains ATP and GTP binding sites [45] and probably provides energy for $\mathrm{Ni}$ activation [46] was present at the amino terminus (positions 19-26) of UreG.

A pH optimum in the acidic range for urease produced by a neutrophile like $Y$. enterocolitica biovar $1 \mathrm{~A}$ was similar to that reported for $Y$. enterocolitica biovars $1 \mathrm{~B}$ and 4 , and Morganella morganii [35,47]. Ureases with optima in the acidic range reportedly carried a phenylalanine seven residues towards $\mathrm{N}$-terminus, and an asparagine one residue toward the C-terminus, from the catalytic site [35]. Both these residues are also present at respective positions in UreC of Y. enterocolitica biovar 1A. The maximal activity of urease at $65^{\circ} \mathrm{C}$ by Y. enterocolitica biovar $1 \mathrm{~A}$ has also been reported for other bacteria [44]. A low $\mathrm{K}_{\mathrm{m}}$ of $Y$. enterocolitica biovar 1A urease as in biovar 4 strains [47], indicated its high affinity for urea. This suggested that the enzyme might function quite normally in the gut despite low concentrations (1.7-3.4 mM) of the urea available there. Also, consistent with our observation, organisms which produce urease with low $\mathrm{K}_{\mathrm{m}}$ have been reported to possess urea transport ( $y u t$ ) gene as seen in S. salivarius, Lactobacillus fermentum, Bacillus sp. strain TB-90 and B. suis [48].

The cultural conditions which affected production of urease by $Y$. enterocolitica biovar $1 \mathrm{~A}$ included growth phase, growth temperature and availability of nickel ions. The expression of bacterial ureases is known to be either constitutive or induced by factors like low nitrogen, urea or $\mathrm{pH}$ [49]. The maximal urease activity during stationary phase of the growth and at $28^{\circ} \mathrm{C}$ as observed for Y. enterocolitica biovar 1A strain was consistent with that of biovar 4 strains [47]. In $Y$. enterocolitica, several other virulence factors such as invasin, Myf fibrillae and enterotoxin have also been reported to be regulated by growth phase and the growth temperature [50]. A 10-fold increase in urease activity following supplementation of growth medium with nickel was not accompanied by increase in the expression of urease structural proteins suggesting that increased activity was probably due to the activation of pre-existing apoenzyme. Nickel has been reported to regulate both expression and activity of urease in $\mathrm{H}$. pylori [51]. In silico analysis of whole genome of $Y$. enterocolitica 8081 (biovar 1B) revealed two systems (ureH and $y n t$ ) for transport of nickel. It would be interesting to determine 
the role of multiple nickel transport genes in urease activity and its regulation in Y. enterocolitica.

The $\mathrm{M}_{\mathrm{w}}$ of $Y$. enterocolitica biovar 1A urease as assessed from native PAGE was $>545 \mathrm{kDa}$. The molecular mass of urease is known to vary from as low as $130 \mathrm{kDa}$ in B. suis [52] to as high as $620 \mathrm{kDa}$ in Providencia rettgeri or $>700$ $\mathrm{kDa}$ in M. morganii [53]. The difference in the molecular mass of urease of Y. enterocolitica biovar 1A vis-à-vis Y. enterocolitica biovar $1 \mathrm{~B}$ and biovar 4 seems to be due to difference in the size of UreB ( $\beta$-subunit), which is smaller in the former and thus may account for its lower molecular mass. The isoelectric point (pI) of 5.2 of biovar 1A urease was close to that reported for Proteus penneri ( $\mathrm{pI}=5.1$ ) and H. pylori $(\mathrm{pI}=5.9)$ urease $[33,54]$. No data on molecular mass and isoelectric point of ureases produced by Y. enterocolitica strains belonging to other biovars has been reported.

The ability of $Y$. enterocolitica biovar 1A strains to survive at $\mathrm{pH} 2.5$ in vitro in the presence of $3.4 \mathrm{mM}$ urea implicated urease in their survival. This suggested the possible role urease might play in the survival of $Y$. enterocolitica biovar 1A under acidic conditions in the gut. However, this needs to be confirmed by comparison of wild type strain with an isogenic urease mutant. The role of urease in survival during transit through gut has been reported for $B$. suis, $B$. abortus, $H$. pylori and $E$. ictaluri $[18,19,36,55,56]$. Interestingly, the biovar 1A strains have also been reported to resist killing, and survive within macrophages [13]. It would therefore be worthwhile to determine the role urease may play in the survival of $Y$. enterocolitica biovar 1A strains in the acidic environment of phagolysosomes.

\section{Conclusions}

The ure gene cluster of $Y$. enterocolitica biovar 1A though broadly similar to that of biovar $1 \mathrm{~B}$ and biovar 4 strains showed differences in structural (ureB) genes and the intergenic regions thereof. The kinetic data indicated that urease produced by $Y$. enterocolitica biovar 1A strain would be active at low concentration of urea typically present in the gut. The ability of biovar 1A strain to survive at acidic $\mathrm{pH}$ in the presence of urea suggested that urease might play role in their survival in the gut. This however needs to be corroborated using ure isogenic mutants.

\section{Authors' contributions}

NB carried out the experimental part of the study. JSV conceived and supervised the work. Both authors participated in interpretation of data and preparation of the final manuscript.

\section{Additional material}

\section{Additional file 1}

Nucleotide and deduced amino acid sequences of ure gene cluster of Y. enterocolitica biovar 1A. The nucleotide sequence of the ure gene cluster of $\mathrm{Y}$. enterocolitica biovar $1 \mathrm{~A}$ and the deduced amino acid sequences of the structural $(A, B$, and $C)$ and accessory $(E, F, G$ and $D)$ proteins are shown. Putative ribosome binding site consensus sequences upstream of ureA, ureB, ureC, ureF and ureG are in bold face. Stop codons are indicated by an asterisk.

Click here for file

[http://www.biomedcentral.com/content/supplementary/14712180-9-262-S1.PDF]

\section{Additional file 2}

Phylogenetic relationships of urease structural (UreA, UreB and UreC) proteins. Dendrograms showing phylogenetic relationships of Yersinia spp. including Y. enterocolitica biovar $1 \mathrm{~A}$ and other bacterial species based on amino acid sequence of urease structural proteins (UreA, UreB and UreC). The trees were constructed by the neighbor joining method in MEGA 4.0 package. The bootstrap values presented at corresponding branches were evaluated from 1,000 replications. GenBank accession numbers are indicated for strains used in creating the dendrogram. The bar scale shows substitutions per site.

Click here for file

[http://www.biomedcentral.com/content/supplementary/14712180-9-262-S2.PDF]

\section{Additional file 3}

Phylogenetic relationships of urease accessory (UreE, UreF UreG and UreD) proteins. Dendrograms showing phylogenetic relationships of Yersinia spp. including Y. enterocolitica biovar $1 \mathrm{~A}$ and other bacterial species based on amino acid sequence of urease accessory proteins (UreE, UreF, Ure G and UreD). The trees were constructed by the neighbor joining method in MEGA 4.0 package. The bootstrap values presented at corresponding branches were evaluated from 1,000 replications. GenBank accession numbers are indicated for strains used in creating the dendrogram. The bar scale shows substitutions per site.

Click here for file

[http://www.biomedcentral.com/content/supplementary/14712180-9-262-S3.PDF]

\section{Additional file 4}

PCR-RFLP of ureAB of Y. enterocolitica. DNA was amplified with primers ureAB3-ureAB4 and restriction digested using (A) HaeIII and (B) Sau96I enzymes. Lanes 1: IP27403, 2: IP26305, 3: E1281550, 4: P346, 5: P472, 6: IP27387, 7: STM 126, 8: 0310/90, 9: IP27938, 10: IP27879, 11: IP27873, 12: IP24121, 13: IP134, 14: IP26329, 15: IP26249, 16: 8081. M: Molecular mass marker (100 bp ladder, New England BioLabs); BV: biovar.

Click here for file

[http://www.biomedcentral.com/content/supplementary/14712180-9-262-S4.PDF] 


\section{Additional file 5}

Effect of urea/nickel chloride on activity (A) and expression (B) of urease of Y. enterocolitica. Strain IP27403 was grown in Luria Broth (LB) or in LB supplemented with $16.7 \mathrm{mM}$ urea (LB-urea) or $\mathrm{NiCl}_{2}$ at 1 $\mu \mathrm{M}$ (Ni-1), $10 \mu \mathrm{M}$ (Ni-10), $100 \mu \mathrm{M}$ (Ni-100) and $200 \mu \mathrm{M}$ (Ni-200) concentration. M: Medium range protein ladder (Bangalore Genei). Data points represent mean of triplicate determinations; error bars denote standard deviation.

Click here for file

[http://www.biomedcentral.com/content/supplementary/14712180-9-262-S5.PDF]

\section{Acknowledgements}

This work was supported by research grants to JSV from Indian Council of Medical Research (ICMR) and Defence Research and Development Organization (DRDO) and Senior Research Fellowship to NB from Indian Council of Medical Research (ICMR), New Delhi. The financial assistance from University of Delhi to strengthen $R$ \& $D$ doctoral research programme is also acknowledged gratefully.

\section{References}

I. Bottone E): Yersinia enterocolitica: overview and epidemiologic correlates. Microbes Infect 1999, I:323-333.

2. Leclercq A, Martin L, Vergnes ML, Ounnoughene N, Laran JF, Giraud $P$, Carniel E: Fatal Yersinia enterocolitica biotype 4 serovar 0:3 sepsis after red blood cell transfusion. Transfusion 2005, 45:8I4-8I8

3. Cornelis GR, Boland A, Boyd AP, Geuijen C, Iriarte M, Neyt C, Sory MP, Stainier I: The virulence plasmid of Yersinia, an antihost genome. Microbiol Mol Biol Rev 1998, 62:1315-1352.

4. Revell PA, Miller VL: Yersinia virulence: more than a plasmid. FEMS Microbiol Lett 200I, 205:I59-164.

5. Tennant SM, Grant TH, Robins-Browne RM: Pathogenicity of Yersinia enterocolitica biotype IA. FEMS Immunol Med Microbiol 2003, 38:127-137.

6. Morris JG Jr, Prado V, Ferreccio C, Robins-Browne RM, Bordun AM, Cayazzo M, Kay BA, Levine MM: Yersinia enterocolitica isolated from two cohorts of young children in Santiago, Chile: incidence of and lack of correlation between illness and proposed virulence factors. / Clin Microbiol I 99I, 29:2784-2788.

7. Burnens AP, Frey A, Nicolet J: Association between clinical presentation, biogroups and virulence attributes of Yersinia enterocolitica strains in human diarrhoeal disease. Epidemiol Infect 1996, I 16:27-34.

8. Ratnam S, Mercer E, Picco B, Parsons S, Butler R: A nosocomial outbreak of diarrheal disease due to Yersinia enterocolitica serotype O:5, biotype I. J Infect Dis 1982, 145:242-247.

9. Greenwood MH, Hooper WL: Excretion of Yersinia spp. associated with consumption of pasteurized milk. Epidemiol Infect 1990, 104:345-350.

10. Bissett ML, Powers C, Abbott SL, Janda JM: Epidemiologic investigations of Yersinia enterocolitica and related species: sources, frequency, and serogroup distribution. I Clin Microbiol 1990 28:910-912.

II. Grant T, Bennett-Wood V, Robins-Browne RM: Identification of virulence-associated characteristics in clinical isolates of Yersinia enterocolitica lacking classical virulence markers. Infect Immun 1998, 66: I I 13-1 I20.

12. Singh I, Virdi JS: Interaction of Yersinia enterocolitica biotype IA strains of diverse origin with cultured cells in vitro. Jpn J Infect Dis 2005, 58:31-33.

13. Grant T, Bennett-Wood V, Robins-Browne RM: Characterization of the interaction between Yersinia enterocolitica biotype IA and phagocytes and epithelial cells in vitro. Infect Immun 1999, 67:4367-4375

14. Bhagat N, Virdi JS: Distribution of virulence-associated genes in Yersinia enterocolitica biovar IA correlates with clonal groups and not the source of isolation. FEMS Microbiol Lett 2007 , 266:177-183.

15. Tennant SM, Skinner NA, Joe A, Robins-Browne RM: Homologues of insecticidal toxin complex genes in Yersinia enterocolitica biotype IA and their contribution to virulence. Infect Immun 2005, 73:6860-6867.

16. McNally A, La Ragione RM, Best A, Manning G, Newell DG: An aflagellate mutant Yersinia enterocolitica biotype IA strain displays altered invasion of epithelial cells, persistence in macrophages, and cytokine secretion profiles in vitro. Microbiology 2007, I 53:1339-1349.

17. Jones BD, Lockatell CV, Johnson DE, Warren JW, Mobley HL: Construction of a urease-negative mutant of Proteus mirabilis: analysis of virulence in a mouse model of ascending urinary tract infection. Infect Immun 1990, 58: I I20-I I23.

18. Marshall BJ, Barrett LJ, Prakash C, McCallum RW, Guerrant RL: Urea protects Helicobacter (Campylobacter) pylori from the bactericidal effect of acid. Gastroenterology 1990, 99:697-702.

19. Sangari FJ, Seoane A, Rodríguez MC, Agüero J, García Lobo JM: Characterization of the urease operon of Brucella abortus and assessment of its role in virulence of the bacterium. Infect Immun 2007, 75:774-780.

20. de Koning-Ward TF, Robins-Browne RM: Contribution of urease to acid tolerance in Yersinia enterocolitica. Infect Immun 1995, 63:3790-3795.

21. Gripenberg-Lerche C, Zhang L, Ahtonen P, Toivanen P, Skurnik M: Construction of urease-negative mutants of Yersinia enterocolitica serotypes 0:3 and 0:8: role of urease in virulence and arthritogenicity. Infect Immun 2000, 68:942-947.

22. Sachdeva P, Virdi JS: Repetitive elements sequence (REP/ ERIC)-PCR based genotyping of clinical and environmental strains of Yersinia enterocolitica biotype IA reveal existence of limited number of clonal groups. FEMS Microbiol Lett 2004, 240:193-201.

23. de Koning-Ward TF, Ward AC, Robins-Browne RM: Characterisation of the urease-encoding gene complex of Yersinia enterocolitica. Gene 1994, 145:25-32.

24. Skurnik M, Batsford S, Mertz A, Schiltz E, Toivanen P: The putative arthritogenic cationic 19-kilodalton antigen of Yersinia enterocolitica is a urease $\beta$-subunit. Infect Immun 1993, 6 I:2498-2504.

25. Campanella JJ, Bitincka L, Smalley J: MatGAT: an application that generates similarity/identity matrices using protein or DNA sequences. BMC Bioinformatics 2003, 4:29.

26. GeneMark [http://exon.biology.gatech.edu/
[ genemark prok gms plus.cgi]

27. GeneMark.hmm [http://exon.gatech.edu/gmhmm2 prok.cgi]

28. FGENESB [http://www.softberry.com/berry.phtml]

29. NCBI ORF finder [http://www.ncbi.nlm.nih.gov/gorf/gorf.html]

30. Gulati P, Varshney RK, Virdi JS: Multilocus variable number tandem repeat analysis as a tool to discern genetic relationships among strains of Yersinia enterocolitica biovar IA. J Appl Microbiol 2009, 107:875-884

31. Bradford M: A rapid and sensitive method for the quantitation of microgram quantities of protein utilizing the principle of protein-dye binding. Anal Biochem 1976, 72:248-254.

32. McGee DJ, May CA, Garner RM, Himps JM, Mobley HL: Isolation of Helicobacter pylori genes that modulate urease activity. J Bacteriol 1999, I 8 I :2477-2484.

33. Mobley HL, Jones BD, Penner JL: Urease activity of Proteus penneri. J Clin Microbiol 1987, 25:2302-2305.

34. Sambrook J, Fritsch EF, Maniatis T: Molecular cloning: a laboratory manual. Cold Spring Harbor Laboratory Press C.S.H., New York; 1989.

35. Young GM, Amid D, Miller VL: A bifunctional urease enhances survival of pathogenic Yersinia enterocolitica and Morganella morganii at low pH. J Bacteriol 1996, 178:6487-6495.

36. Booth $\mathrm{Nl}$ : The role of urease in the pathogenesis of Edwardsiella ictaluri. In Ph.D thesis Louisiana State University, Department of Pathobiological Sciences, Baton Rouge; 2005.

37. Heermann R, Fuchs TM: Comparative analysis of the Photorhabdus luminescens and the Yersinia enterocolitica genomes: uncovering candidate genes involved in insect pathogenicity. BMC Genomics 2008, 9:40.

38. Chen YY, Clancy KA, Burne RA: Streptococcus salivarius urease: genetic and biochemical characterization and expression in a dental plaque streptococcus. Infect Immun 1996, 64:585-592. 
39. Collier JL, Brahamsha B, Palenik B: The marine cyanobacterium Synechococcus sp. WH7805 requires urease (urea amidohydrolase, EC 3.5.1.5) to utilize urea as a nitrogen source: molecular-genetic and biochemical analysis of the enzyme. Microbiology 1999, 145:447-459.

40. Park IS, Hausinger RP: Site-directed mutagenesis of Klebsiella aerogenes urease: identification of histidine residues that appear to function in nickel ligation, substrate binding, and catalysis. Protein Sci 1993, 2: 1034-I04I.

41. Jabri E, Carr MB, Hausinger RP, Karplus PA: The crystal structure of urease from Klebsiella aerogenes. Science 1995, 268:998- 1004.

42. Todd MJ, Hausinger RP: Identification of the essential cysteine residue in Klebsiella aerogenes urease. J Biol Chem 1991, 266:24327-2433I.

43. Mulrooney SB, Hausinger RP: Sequence of the Klebsiella aerogenes urease genes and evidence for accessory proteins facilitating nickel incorporation. J Bacteriol 1990, 172:5837-5843.

44. Bossé JT, Maclnnes Jl: Genetic and biochemical analyses of Actinobacillus pleuropneumoniae urease. Infect Immun 1997, 65:4389-4394.

45. Saraste M, Sibbald PR, Wittinghofer A: The P-loop: a common motif in ATP- and GTP-binding proteins. Trends Biochem Sci 1990, 15:430-434.

46. Moncrief MB, Hausinger RP: Characterization of UreG, identification of a UreD-UreF-UreG complex, and evidence suggesting that a nucleotide-binding site in UreG is required for in vivo metallocenter assembly of Klebsiella aerogenes urease. J Bacteriol 1997, 179:408|-4086.

47. de Koning-Ward TF, Robins-Browne RM: A novel mechanism of urease regulation in Yersinia enterocolitica. FEMS Microbiol Lett 1997, I 47:221-226.

48. Sebbane F, Bury-Moné S, Cailliau K, Browaeys-Poly E, De Reuse H, Simonet M: The Yersinia pseudotuberculosis Yut protein, a new type of urea transporter homologous to eukaryotic channels and functionally interchangeable in vitro with the Helicobacter pylori Urel protein. Mol Microbiol 2002, 45: I 165-I I 74.

49. Mobley HL, Island MD, Hausinger RP: Molecular biology of microbial ureases. Microbiol Rev 1995, 59:45I-480.

50. Straley SC, Perry RD: Environmental modulation of gene expression and pathogenesis in Yersinia. Trends Microbiol 1995, 3:310-317.

5I. van Vliet AH, Kuipers EJ, Waidner B, Davies BJ, de Vries N, Penn CW, Vandenbroucke-Grauls CM, Kist M, Bereswill S, Kusters JG: Nickelresponsive induction of urease expression in Helicobacter pylori is mediated at the transcriptional level. Infect Immun 200I, 69:489I-4897.

52. Contreras-Rodriguez A, Quiroz-Limon J, Martins AM, Peralta $H$, Avila-Calderon E, Sriranganathan N, Boyle SM, Lopez-Merino A Enzymatic, immunological and phylogenetic characterization of Brucella suis urease. BMC Microbiol 2008, 8:121.

53. Jones BD, Mobley HL: Genetic and biochemical diversity of ureases of Proteus, Providencia, and Morganella species isolated from urinary tract infection. Infect Immun 1987, 55:2198-2203.

54. Mobley HL, Cortesia MJ, Rosenthal LE, Jones BD: Characterization of urease from Campylobacter pylori. J Clin Microbiol 1988, 26:83I-836.

55. Bandara $A B$, Contreras $A$, Contreras-Rodriguez A, Martins AM, Dobrean V, Poff-Reichow S, Rajasekaran P, Sriranganathan N, Schurig GG, Boyle SM: Brucella suis urease encoded by urel but not ure2 is necessary for intestinal infection of BALB/c mice. BMC Microbiol 2007, 7:57.

56. Thune RL, Fernandez DH, Benoit JL, Kelly-Smith M, Rogge ML, Booth NJ, Landry CA, Bologna RA: Signature-tagged mutagenesis of Edwardsiella ictaluri identifies virulence-related genes, including a salmonella pathogenicity island 2 class of type III secretion systems. Appl Environ Microbiol 2007, 73:7934-7946.

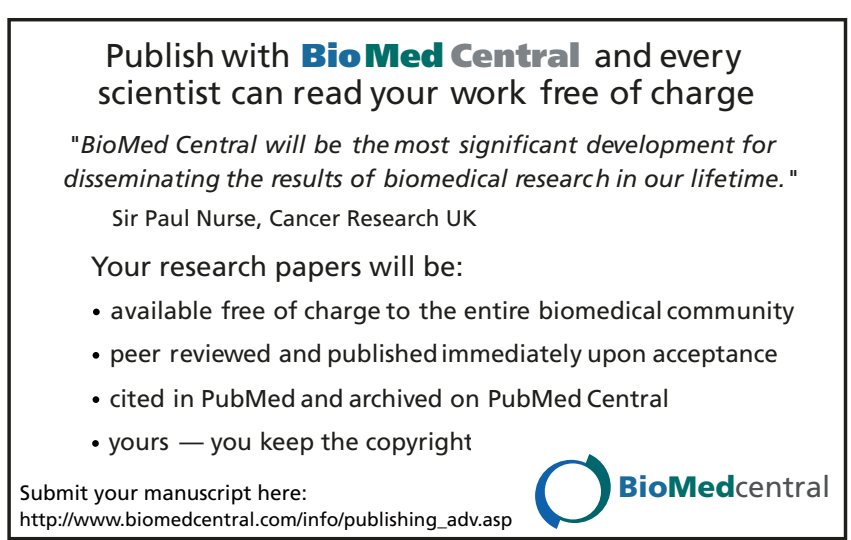

